\title{
What factors Influence Internal migration and Wage Growth? an Empirical Analysis of Private Formal Sector in Bolgatanga-Ghana
}

\author{
Nicholas Awuse (Corresponding author) \\ Bolgatanga Polytechnic \\ P. O. Box 767, Sumbrungu, Bolgatanga, Ghana \\ Tel: 233-243-924-839 E-mail: akaare2002@yahoo.com \\ Patrick Tandoh-Offin $(\mathrm{PhD})$ \\ Ghana Institute of Management and Public Administration (GIMPA) \\ P. O. Box AH-50, Achimota-Accra, Ghana \\ Tel: 233-247-450-433 E-mail: ptandoh@gimpa.edu.gh
}

Received: November 3, 2013 Accepted: November 25, 2013

doi:10.5296/ber.v4i1.4973 URL: http://dx.doi.org/10.5296/ber.v4i1.4973

\begin{abstract}
The primary aim of this study is to explore the determinants of wage growth velocity in personal formal sector of Bolgatanga Municipality. A primary data collection technique was used and sample size of 345 individuals interviewed using a well structured interview schedule and questionnaire by convenient sampling. Ordinary least square method was applied to study the dependency of growth rate of wage on different variables in Bolgatanga Municipality. Findings reveal that education, gender, experience, household area and marital status of the respondents absolutely affect growth of wages at less than $1 \%$ level of significance.
\end{abstract}

Keywords: Wage Growth, Private Formal, Bolgatanga, Education, Gender, Experience, internal migration, Household area, Marital Status, Ghana.

\section{Introduction}

Conventionally high wages were linked to high education. According to the theorists of human capital wages were intended to reward workers in progress and future revenues, graduates with advanced levels of education should be paid more than graduates with lower levels of 
education. As a result, savings in education graduates may look forward to be paid with certain "superfluous" financial return (Becker, 1964). Spence (1973) came out with alternative theory to explain the salary bonus paid to academic degree holders. He argued that graduates may acquire some natural skills compulsory to get the educational credential; accordingly, despite the consequences the potential human capital gains obtained in the university, the degree would act as a signal of such natural superior ability. It was estimated that in 2001, close to 120 million people were estimated to migrate internally in China, compared to the mere 458,000 people migrating internationally for work (Ping 2003). In India too, internal migration numbers run into millions while international migration was only a fraction of this (Srivastava and Sasikumar 2003). In Ghana it was estimated that more than $70 \%$ of the total population migrated internally over the years.

Becker (1962) and Mincer (1974) have long-established that education and schooling were the core determinants of human resources buildup and in turn, positively and frankly related with individuals lifetime wage earning. Proceeds to education in Mincerian earning function denoted with coefficient of school years that was, how much extra wage earning was taking place with an extra year of schooling. There was enough literature availability to examine the return to education for various countries including Ghana. In Bolgatanga, most household surveys made available sufficient information about many variables such as, completed years of schooling, starting school age, school quality and teaching related to technical education.

As a result of variables like lost data on school years completed, researcher can neither estimate probable experience nor compute the impact of one extra year of schooling on respondent's wage earnings. Consequently, the existing literature in Ghana was missing in functioning out total returns to education presented by Mincerian earning function.

In this study, we would scrutinize the determinants of wage growth of persons. For measuring wage growth of individuals we have taken a case study of Bolgatanga. Ghana has ten administrative regions: These regions are; Greater Accra; Ashanti, Northern, Western, Eastern, Volta, Brong Ahafo, Central, Upper East and West Regions.

Bolgatanga municipality is located at the North Eastern part of Ghana. Bolgatanga Municipality has three zonal districts, namely Sumbrungu-Sirigu, Bolgatanga Central and Zuarungu.

The main objective (s) of this study was among other thing to estimate the factors that determine the wage growth of individuals in Bolgatanga Municipality. Series of research has been conducted in this area nevertheless there was no study that touched on wage growth of private ceremonial sector in Bolga, that calls for supplementary research work. The conclusion of this work would be very supportive for the determinants of Wage growth of private formal sector in Bolga.

\section{Literature Review}

According to the literature review on determinants of wage of individuals; Hawke, Anne (1998); explored the impact of computer skills on wage for males and females in Australia. Applying OLS method on the data taken from 1993 Survey of Training and education 
experience, it was disclosed that the effect of usage of computer on wage earning differs with respect to different types of uses. Computer skills itself do not determine the labour market returns, nevertheless, returns to computer skills were depend upon the type of used.

According to Faridi et. al., (2010); investigated the effect of different level of education on students' earnings. Applying OLS method on data collected from ground inspection about different levels of education of students it was found that years of completed education \& experience are positively interrelated to income of students.

In addition, the above; Ekstrom and Erika (2003); examined the impact of obligatory and upper secondary level of education on earning of individuals using longitudinal individual data. Applying OLS technique on longitudinal individual data she concluded that adult secondary education caused reduction in earnings in case of Swedish males. However, no evidence was found for Swedish females.

Soto (2009); investigated the causality between education and aggregate level of income. By using panel regression, he found that there is a link between completed years of schooling and Gross Domestic Product (GDP). Most important conclusion of this study was that an important determinant of income disparity was quality of schooling.

It was also revealed that Shah (2007); conducted research and concluded determinants of women's earnings. Model was based on Mincerian equation. Applying Mincerian model on data gather on experience, level of education and monthly salary of female teachers from public educational institutions and conclude that there was positive consequence of higher education on earning of female teachers.

It was revealed Moheyuddin (2005); explored connection between gender discrepancy in level of education, income, growth \& development. He has completed and that there is positive relationship between improvements in gender equality and per capita income, and for economic growth gender inequality was not good.

Comi and Brunello (2000); explored the relationship between education and the effects of education on growth of earnings. They collected the Cohort data from eleven European countries and they found differences in growth of earnings at different levels of education.

Tinbergen (1971); explored the effects of education on distribution of income. He used cross sectional data and concluded that dispersion in years of education while these dispersions are higher or smaller would reduce level of inequality in USA, Neither land \& Canada moderately only.

According to Asadullah and Niaz (2005); investigated the total labour market returns in Bangladesh. Using Mincer-Beckerian approach revealed that there is much heterogeneity in returns. Estimates of earning returns were higher for urban sample than rural, and also higher for female than male sample. Method applied on the model was OLS method.

Dah et. al., (2006); explored the determinants of male and female earnings in Urban Lebanon. Applying multiple Regression analysis on cross-sectional data of labor force they found that there is gender differential in earnings in Lebanon. 
Aslam and Munazza (2002); investigated the determinants of private return to education for male and female wage earner in Pakistan. Applying OLS, Heckman Correction, 2SLS and Household fixed effects on Pakistan Integrated Household Survey (2002) they found that total labor market returns are higher for males but the returns to education are higher for females.

As a result of the above conclusion, it was recommended that there is likelihood that parents may have an encouragement to assign more possessions in boys than to girls within the same household.

\section{Research Methodology}

The methodology looks at a model specification, data requirements and source of data. The study was based on primary data taken from Bolgatanga. The data was collected to see how growth of earning of individuals was pretentious by many explanatory variables like education, gender, experience, household locality, age and marital status.

In Ghana for example, about $40 \%$ of the total population moved within the country, and out of these number, about $70 \%$ of migrants came mostly from the three northern regions (Northern, Upper East and Upper West) and Volta regions towards the cocoa growing and mineral deposits areas in the southern parts of the country especially Ashanti and Western Regions. However, the remaining regions moved within urban centres and outside the country for better living conditions.

Bolgatanga is the area of our research. The complete population related to formal and private sector in Bolgatanga were considered world of our study. The relevant data for the study was collected from primary sources. A random sampling method was adopted in order to categorize a sample, where each working person in private sector was discovered and interviewed. During the interview, we asked some questions to the People related to their educations, age, experiences. Our sample size was 345 respondents in Bolgatanga. The interview schedule was used because this was the best tool to gather maximum first hand information. The interview schedule was prepared on the bases of a questionnaire. Each respondent was interviewed through structured questionnaire, as structured question were more reliable and they reduced the error of question wording. For the duration of the preparation of the interview schedule, care was taken not to include, ambiguous, vague and misleading questions, so, that the questions could be communicated accurately resulting in accurate responses. In this study, both open and closed ended question were used. To be sure about the achievability of the interview schedule and to ensure that all questions were being communicated accurately, a pre-testing was conducted in Zaire. After pre-testing, some of the questions which were not found appropriate were dropped and some of the questions were customized and added. The interview was completed in 3 weeks. Respondents were asked to express their true personal attitudes and experiences about this particular issue. After interviewing, all the respondents data was edited.

\subsection{Logs-Linear Regression}

Log Linear regression was an approach to modeling the association between a dependent and independent variable in which regressand (dependent variable) was Logarithmic because it 
measures growth of dependent variable.

\subsection{Model Specification and Operational Definitions of Variables}

According to our research requirement we have to analyze the impact of variables like education, gender, marital status, household area and experience on log wage. Our model was log-linear model.

The relationship between the dependent and independent variable is;

Log wage $=\mathrm{f}$ (education, gender, experience, household area, marital status, age)

Log wage $=$ loge wage measured as log of cedis earned per month.

Education $=$ education measured as Intermediate $=0$, Graduation $=1$, Masters $=2$

Gender $=$ Define gender as Male $=1$, Female $=0$

Age $=0-15=0,16-25=1,26-35=2,36-45=3$

Household $=$ Define household locality as $\operatorname{Urban}=1$, Rural $=0$

Marital status $=$ Define marital status Married $=1$, Single $=0$, divorced $=2$, separated $=3$

\section{Results and Discussion}

Analysis of data was done using ordinary least square method in stata. Factors of internal migration and growth rate of wage of private formal sector was explored using log-lin model. Log wage was regressed on gender, age, education, experience, household area and marital status.

Table 1. Model Summary

\begin{tabular}{|l|l|l|l|l|l|}
\hline Model & R & R-Square & Adjusted R Square & Standard Error Estim & Durbin Watson \\
\hline 1 & 0.0173 & 0,030 & 0.013 & 1.26805 & 1.565 \\
\hline
\end{tabular}

Source: Field Work 2013

Table 1 explains various measures of model fitness as $R^{2}$, Adjusted $R^{2}$ and Durbin Watson $d$ statistic for the detection of model specification error and autocorrelation. The co-efficient of determination $\mathrm{R}^{2}$ was an important measure of goodness of fit of fitted regression model that was found out how "well" the sample regression line fits the data.

More simply, it shows the proportion of variations in dependent variable due to all explanatory variables included in the model. Its value always lie between 0 and 1 , greater the value of $R^{2}$ larger (closer to 1 ) the evidence of goodness of fits. In our study $R^{2}=0.030$ which shows total variations in log wage was due to all the explanatory variables like gender, education, Experience, Household area and marital status.

Predictors: (Constant), gender, education, Experience, Household area, marital status

We increased the number of explanatory variables than $\mathrm{R}^{2}$ increases, to control this effect we adjust the degrees of freedom in $\mathrm{R}^{2}$ and obtain adjusted $\mathrm{R}^{2}$. The value of Adjusted $\mathrm{R}^{2}$ shows 
that variations in log wage due adjusted fluctuations in all explanatory variables included in our model.

We used Durbin Watson d statistic to detect autocorrelation and any type of specification error in our regression model. A rule of thumb, if the value of Durbin-Watson is 2 in an application, than it can be believed that there is no autocorrelation, either positive or negative. Table 1shows that in our model DW is 1.555 so, using table values of DW it is observed that there is no autocorrelation or any type of model specification error.

Predictors: (Constant), gender, education, Experience, Households area, Marital Status

Table 2. ANOVA

\begin{tabular}{|l|l|l|l|l|l|}
\hline Model & Sum of Squares & Df & Mean Square & F. Sig & \\
\hline Regression & 16.765 & 6 & 2.793 & 1.737 & 0.112 \\
\hline Residuals & 543.490 & 338 & 1.608 & & \\
\hline Total & 560.249 & 344 & & & \\
\hline
\end{tabular}

Source: Field Work 2013

Table 2 gives ANOVA that explains total variations (TSS) in explained (ESS) and unexplained or residual (RSS) variations. In our study ESS is 16.765 which are $0.030 \%$ of total variations and this is variations in log wage due to fluctuations in all explanatory variables.

The residual sum of square shows the variations in dependent variable that were not due to explanatory variables included in our model. RSS in our study was 543.490 indicates that there was 543.490 variations in log wage due to residuals which was total variations. The use of F-test statistic is made in order to examine the overall significance of the model. Value of F-test statistic is 1.737 which shows that model was not significant at 100 percent confidence level.

Table 3. Shows regression coefficients

\begin{tabular}{|c|c|c|c|c|c|c|c|}
\hline Model & \multicolumn{2}{|c|}{$\begin{array}{c}\text { Substandard } \\
\text { Coefficients }\end{array}$} & $\begin{array}{c}\text { Standard } \\
\text { Error }\end{array}$ & \multicolumn{3}{|c|}{ t. Signif } & \multicolumn{2}{c|}{ Collinearity } \\
\hline & $\mathrm{B}$ & $\begin{array}{c}\text { Standard } \\
\text { Error }\end{array}$ & Beta & $\mathrm{T}$ & $\mathrm{Si}$ & Tolerance & $\begin{array}{c}\text { VIF(variance } \\
\text { inflation factor) }\end{array}$ \\
\hline constant & 2.968 & 1.425 & & 6.988 & 0.000 & & .907 \\
\hline gender & 0.021 & 1.138 & 0.008 & -0.0152 & 0.88 & .997 & 1.003 \\
\hline education & 0.006 & 0.042 & 0.008 & 0.143 & 0.0886 & .980 & 1.020 \\
\hline experience & -0.072 & 0.046 & 0.085 & -1.580 & 0.115 & .981 & 1.020 \\
\hline $\begin{array}{c}\text { Household } \\
\text { area }\end{array}$ & 0.009 & 0.011 & 0.045 & 0.0822 & 0.0412 & .971 & 1.030 \\
\hline $\begin{array}{c}\text { Marital } \\
\text { status }\end{array}$ & 0.050 & 0.025 & 0.105 & 1.958 & 0.051 & .988 & 1.012 \\
\hline age & 0.256 & 0.134 & 0.104 & 1.911 & 0.057 & .977 & 1.023 \\
\hline
\end{tabular}

Source: Field Work, 2013

All explanatory variables are given in table 3 with their coefficients, level of significance and collinearity statistics as Tolerance and Variance Inflating Factor (VIF). The coefficient of 'Education' is 0.021 which shows that after controlling the effect of all the variables, wage will increase $0.006 \%$ due to every higher level of education and this result was highly statistically significant at zero percent significance level. 
A person having high level of education earns more wages in Ghana than a person having low level of education. Therefore, education has a significant role in determining the wages of respondents.

The coefficient of 'Experience' shows that after controlling for all the variables, wage will increase $7.2 \%$ due to one year increase in experience. And t value is -1.58 that is not significant value which is clear from level of significance. Coefficient of household area which is 0.009 is also significant at $0.000 \%$ level of significance. Wage will increase $0.009 \%$ due to change in household area (Rural to Urban). And t value is 0.082 that is also highly not statistically significant value. From evidence it is clear that a person located in urban area earns 0.009 percent more than a person located in rural area. Coefficient of marital status is 1.95 which means wages will increase $0.050 \%$ as a person gets married. All of these factors significantly and positively affect the wage growth of individuals in Bolgatanga.

In our study to check multicollinearity we use Tolerance and Variance inflation factor (VIF) shows in Table 3. The larger was the value of VIF the Higher collinear in the variable $\mathrm{Xj}$. In the limit VIF can be finite in case of perfect collinearity. A rule of thumb, if the VIF of a variable was greater than 10 , which will happen if $\mathrm{R}^{2}$ was higher than 0.90 , that variable was said to be highly collinear. In our study result shows that the value of VIF of variables Gender, Education, Experience, Household locality and marital status are 1.001, 1.019, 1.017, 1.012, and 1.012 respectively. That shows our explanatory variables were not collinear with each other. And multicollinearity doesn't exist in our results among these variables such as Gender, education, experience, household locality and marital status. Another statistic that was inverse of VIF is Tolerance (TOL) is use to check the multicollinearity in our results show in table 3 . The value of TOL is b/w 0-1. The closer is the value of TOL of a variable to 0 , the larger the degree of collinearity of that variable with other Independent variable. On the other hand, the closer TOL of a variable to 1 , the greater the evidence that variable was not collinear with the other regressors.

Our result shows that the value of TOL of variables is closer to 1, which shows no collinearity of a variable with other regressors. The value of TOL of variables gender, education, experience, household locality and marital status are .999, .981, .983, .988, and .989 respectively. Which was evidence that no variable collinear with other regressors in our results.

\section{Conclusion and Recommendations}

This study considers the most important determinants of persons wage development in Bolgatanga Municipality. The results of this study concludes that education; experience, gender; marital status and household area were some major factors that influence individual's earning growth in Bolgatanga-Ghana. As a result of these findings, we cannot object to conclude that level of education, experience, gender; household area and marital status have significant positive collision on wage growth. Marital status of a personality has constructive impact on his/her wage growth as 1 is given to married and 0 otherwise, so, married persons get higher wages in private formal sector as allowances for spouse and children for education and health are added in wages, which consequently increases wages. 
The variable household locality has optimistic shock on wage growth which means that someone living in urban locality has higher wage growth as seen in others for antagonism among employers and higher employment avenues and continuation of well apparent employers in urban centres and also having big city stipend as proportion of primary salary. In the same way, gender has positive impact as males wage growth is superior to females for the difference in output in many jobs particularly in sales and promotion.

As revelations from this study indicated, it was recommended that education should be improved at all levels to enable individuals obtain upper wages in formal private sector. Also, if individuals migrate internally from rural to urban areas, subsequently they get increase in their wages in the form of some allowances or any other way in the cities.

Experience variable should be the overriding principles guiding an increase in wage rather than mere marriage, household size, gender and many other variables.

\section{References}

Anh, D. N. (2003). Migration and Poverty in Asia: With Reference to Bangladesh, China, the Philippines and Viet Nam, Ad Hoc Expert Group Meeting on Migration and Development, organised by the Economic and Social Commission for Asia and the Pacific, Bangkok, 27-29 August.

Asadullah, Niaz. (2005). Returns to education in Bangladesh QEH Working Paper Series QEHWPS130, Working Paper, p. 130.

Aslam, Monazza. (2002). Rates of Return to Education by Gender in Pakistan Global Poverty Research Group (GPRG-WPS-064).

Barone, C., Werfhorst, H. (2008). Education, Cognitive Skills and Earnings in Comparative Perspective, 1-48.

Brunello, G., \& Comi, S. (2000). Education and Earnings Growth: Evidence from 11 European Countries, Economics of Education Review, 23(1), 75-83. http://dx.doi.org/10.1016/S0272-7757 (03)00048-7

Card, D. (1999). The Causal Effect of Education on Earnings, Handbook of Labour Economics, 3, 1802-1859. http://dx.doi.org/10.1016/S1573-4463(99)03011-4

Ekstrom, Erika. (2003). Earnings effects of adult secondary education in Sweden. IFAUInstitute for Labour Market Policy Evaluation, Working Paper, 2003, 16

Faridi, Z., M, Hussain, \& S. Bashir. F. (2010). Impact of Education on Students, Earning, International Research Journal of Finance and Economics, 171-175.

Hawke, Anne. (1998). Gender Differences in Wage Returns to Computes- Skills in Australia, Prometheus, 16(1), 1998. http://dx.doi.org/10.1080/08109029808629249

International Economics Institute, University of Valencia in its series Working Papers with number 0605. 
Lemieuxh, T. (2001). The Causal Effect of Education on Earnings in Canada, 2-16.

M. Dah, Abdallah, \& C. Hammami, Salwa. (2006). Returns to education in Lebanon Lebanese American Uviversity.

Messinis, G. Cheng, E. (2009). Earnings, Education and Training in China: The Migali, G., Walker, I. (2009). Estimates of the Causal Effects of Education on Earnings over the Lifecycle: UK Evidence from a Non-separable Specification with Cohort Effects and Endogenous Education, pp 1-34.

Migrant Worker Experience, Centre for Strategic Economic Studies Working Paper No. 42.

Moheyuddin, G. (2005). Gender inequality in education: Impact on Income, Growth and Development, MPRA Paper No. 685, 01-12.

Pasqua, Silvia. (2005). Gender Bias in Parental Investments in Children's Education: A research Economist at PIDE.

Salles, Mary, A. (2006). Personality, Education and Earnings, Center for Applied Micro econometrics, (CAM), 01-11.

Schultz, T. W. (1961). Investment in Human Capital, the American Economic Review (1).

Soto, M. (2009). The causal effect of education on aggregate income, Paper provided by Springer Science + Business Media, Inc. Manufactured in the Netherlands

Srivastava, R. (2005). India Internal Migration Links with Poverty and Development, country paper regional conference on Migration and Development in Asia, Lanzhou, China, 14- 16 March 2005.

Theoretical Analysis Review of Economics of the Household 3, 291-314, 2005, (C2005

Walker, I., Zhu, Y. (2003). Education, earnings and productivity: recent UK, 145-152.

Zafar Mueen Nasir and Hina Nazli Education and earnings in Pakistan Report 177, Senior.

\section{Copyright Disclaimer}

Copyright reserved by the author(s).

This article is an open-access article distributed under the terms and conditions of the Creative Commons Attribution license (http://creativecommons.org/licenses/by/3.0/). 